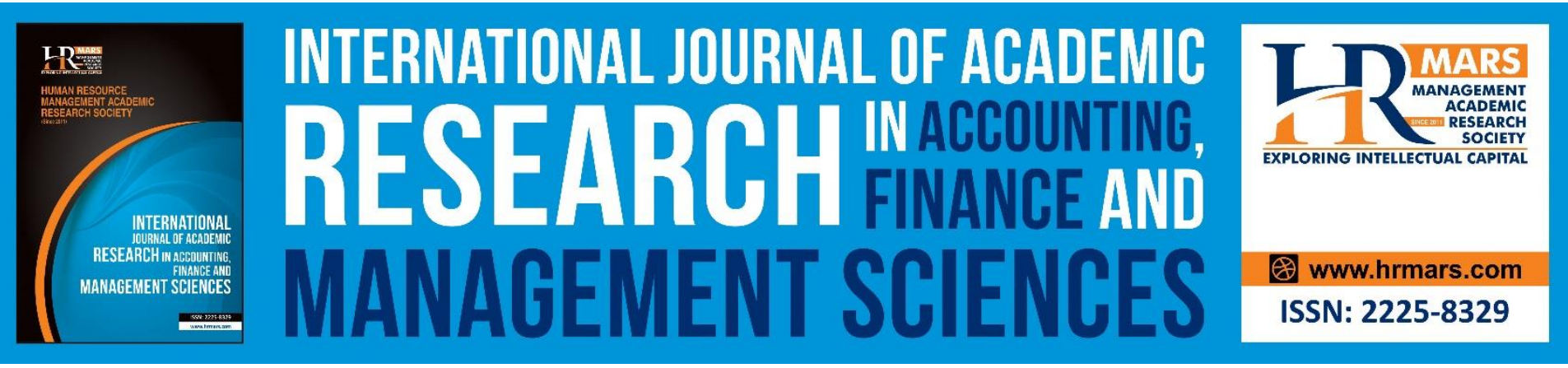

\title{
System Dynamics of Crowdfunding and Quadruple Helix on University Spinoffs Formation in the Ghanaian Context.
}

Francis Kwaku Kuma, Mohd Effandi Yusoff, Jerome Jayamana

To Link this Article: http://dx.doi.org/10.6007/IJARAFMS/v11-i1/9740 $\quad$ DOI:10.6007/IJARAFMS /v11-i1/9740

Received: 21 January 2021, Revised: 25 February 2021, Accepted: 10 March 2021

Published Online: 30 March 2021

In-Text Citation: (Kuma et al., 2021)

To Cite this Article: Kuma, F. K., Yusoff, M. E., \& Jayamana, J. (2021). System Dynamics of Crowdfunding and Quadruple Helix on University Spinoffs Formation in the Ghanaian Context. International Journal of Academic Research in Accounting Finance and Management Sciences, 11(1), 546-566.

Copyright: (c) 2021 The Author(s)

Published by Human Resource Management Academic Research Society (www.hrmars.com)

This article is published under the Creative Commons Attribution (CC BY 4.0) license. Anyone may reproduce, distribute, translate and create derivative works of this article (for both commercial and non-commercial purposes), subject to full attribution to the original publication and authors. The full terms of this license may be seen

at: http://creativecommons.org/licences/by/4.0/legalcode

Vol. 11, No. 1, 2021, Pg. 546 - 566

http://hrmars.com/index.php/pages/detail/IJARAFMS

JOURNAL HOMEPAGE

Full Terms \& Conditions of access and use can be found at http://hrmars.com/index.php/pages/detail/publication-ethics 


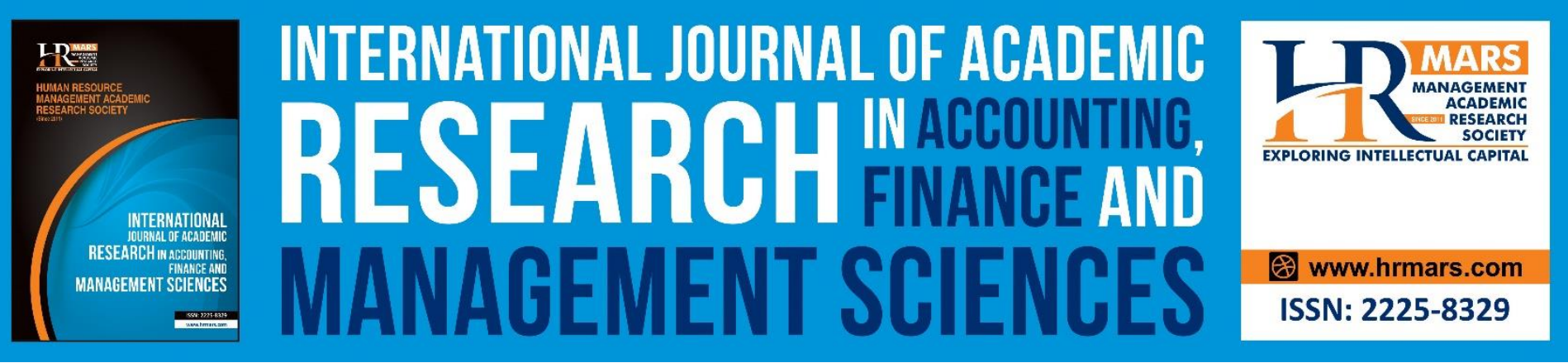

\title{
System Dynamics of Crowdfunding and Quadruple Helix on University Spinoffs Formation in the Ghanaian Context.
}

\author{
Francis Kwaku Kuma \\ Universiti Teknologi Malaysia Skudai, Johor Bahru 81310, Department of Accountancy, Koforidua \\ Technical University, Ghana \\ Email: francis.kwaku.kuma@graduate.utm.my \\ Dr Mohd Effandi Yusoff \\ Universiti Teknologi Malaysia Skudai, Johor Bahru \\ Email: effandi@utm.my \\ Jerome Jayamana \\ Raffles University Iskanda Johor Bahru, Malaysia \\ Email: jeromejayamana@gmail.com
}

\begin{abstract}
The study explores how African countries can develop their own model of knowledge management and high-tech in this era of the Fourth Industrial Revolution (IR 4.0). Specifically, we focused on how the interaction between government, business, academia and societal based innovation users (quadruple helix) can foster innovation and economic prosperity within the Ghanaian context. We further explore how the universities could depend on crowdfunding as alternate finance to establish university spinoffs to enhance knowledge dissemination. Data accrued from fieldwork mainly fell within the scope of qualitative interview materials. The data was coded and categorized into themes and sub-themes for analysis. The findings suggest that there is little interaction between the stakeholders of the helices in Ghana thereby, slowing down knowledge spillover to local communities. Crowdfunding can therefore be an alternate source of funding for Spinoff formation and knowledge development.
\end{abstract}

Keywords: African Context, Spinoffs, Sachet Water, Crowdfunding, Quadruple Helix

\section{Introduction}

The Fourth Industrial Revolution (IR 4.0) has left in its wake major innovations that have necessitated the need for Africa to engage in its own model of knowledge management and technological 
INTERNATIONAL JOURNAL OF ACADEMIC RESEARCH IN ACCOUNTING, FINANCE AND MANAGEMENT SCIENCES

Vol. 11, No. 1, 2021, E-ISSN: 2225-8329 ๔ 2021 HRMARS

development processes. It also calls for the need for African countries to shape the focus of their innovative system frameworks to catch up with the rest of the world. University spinoffs could therefore be instruments that could champion African's version of Fourth Industrial Revolution (IR 4.0) on the continent. This argument stems from the fact that the universities are a cradle of knowledge spillovers and technological innovation. This assertion is in consonance with Mode1 of knowledge production (Gibbons et al. 1994) where the universities are into knowledge-based production and therefore their researches contribute to the growth of the national economy and the development of the society as whole (Carayannis and Campbell 2019a). The study thus aimed at exploring how crowdfunding can boost the formation and growth of university offs in Ghana. In addition, it assess the possibilities of the universities adopting it as alternate startup capital for university spinoff formation. This is because crowdfunding unlike venture capital and business angels will give the universities the advantage of control of their businesses.

Ultimately, because the universities will raise their capital from the crowd they will maintain their right to take decisions for the university spinoffs (Colistra \& Duvall, 2017). Usually raising capital from venture capitalists and business angels through share offers make them part owners of the business. Eventually, the venture capitalists and business angels get involve in the running of the business by being part of the decision making process (Valanciene \& Jegeleviciute, 2013). Raising capital from crowdfunding particularly, donation-based and reward based safeguards the universities from ceding their rights in the decision making process.

Distinctive from previous research, our study aimed at augmenting academic debate on the coming together of academia, government, industry, and societal based innovation users to foster innovation and economic prosperity, specifically, within the Ghanaian context (Ferri, Fiorentino, Parmentola, \& Sapio, 2019). Prior researches have explored a range of approaches to funding university spinoffs but there is limited research on using crowdfunding as an alternative source of funding and its connection to the Quadruple Helix model of innovation. We therefore explored this linkage further by looking at how the various stakeholders in the helix could collaborate to take innovation to the doorstep of the community (Fini, Rasmussen, Siegel, \& Wiklund, 2018). We demonstrate that the universities could depend on crowdfunding as an alternate finance to establish university spinoffs to enhance knowledge dissemination in the Ghanaian context. The question therefore is; can crowdfunding contribute to USO formation in Ghana?

\section{Literature Review}

As discussed in prior literature, the universities are into knowledge-based production and therefore their researches contribute to the growth of the national economy and the development of the society as a whole (Carayannis and Campbell, 2019a). In fact, scholars have found support for the idea that university spinoffs are vital mechanisms for transmitting knowledge to industry because they are avenues for promoting economic development (Bathelt et al., 2010; Meoli et al., 2013; Rasmussen et al., 2006; Walter et al., 2006). Essentially, they are noted for creating knowledge-based employment and dissemination of new technology to improve the regions in which they are located (Mathisen \& Rasmussen, 2019). 
INTERNATIONAL JOURNAL OF ACADEMIC RESEARCH IN ACCOUNTING, FINANCE AND MANAGEMENT SCIENCES

Vol. 11, No. 1, 2021, E-ISSN: 2225-8329 @ 2021 HRMARS

Even though university spinoffs are not a new phenomenon, they have gained prominence in recent times because of their strong economic impact on society (Galvão, Mascarenhas, Rodrigues, Marques, \& Leal, 2017; Lockett \& Wright, 2005; Ramaciotti \& Rizzo, 2015). For instance, research and technology developed by universities are known to have played pioneering roles in firms like Genentech, Lycos and Google (Bonardo et al. 2011). In addition, University spinoffs are greatly involved in the creation of biotech industries. According to Bonardo et al. (2011), about a quarter of all Initial Public Offerings in high-tech industries in Europe are owned by university spinoffs. He explains that university spinoffs in Europe have high shares in most start-up biotech industry, thereby creating high regional impacts. Similarly, (Lawton Smith \& Ho, 2006) indicate that University spinoffs from Oxford University accounts for at least 3.5\% of employment in the local area (Smith \& Romeo, 2012).

Lockett et al., (2005) stress that the development of university spinoffs is achieved through pooling individuals with matching forms of human capital together. They explain that universities that have a greater diversity of internal human resources and proper outside network connections were successful in creating spinoffs because this helps them to have a positive entrepreneurial strategy. Ferri et al., (2019) and Dzisah and Etzkowitz, (2008) emphasized the university spinoffs as being knowledge spill overs from university research which boost economic and social development. Touching on the significant nature of university spinoffs in terms of knowledge transfer, Civera et al., (2017) describes them as economically significant firms which are important mechanisms for transferring new technology to industry. Mathisen and Rasmussen, (2019) broaden their definition by including PRI. They therefore describe University spinoffs as new ventures, which commercialize research results and scientific knowledge from universities, and PRIs. Perhaps, of even more interest is the change of focus of the definition provided by Sipe, (2012). The focus was on University spinoffs being vehicles for commercialisation of technology for the benefit of end users. Sipe, (2012) describe university spinoffs as new firms created to commercially exploit knowledge, technology or research results developed within a university.

\section{Research Methods}

Qualitative data was obtained from three Technical Universities in Ghana which are Technical Vocational Education Training (TVET) institutions, and therefore more likely to establish university spinoffs. The data was gathered using purposive sampling, which targeted academic staff with science and engineering background. The principal instrument used was semi-structured interviews. During the interviews, the proceedings were recorded and later transcribed. The study depended on three predominant stages of qualitative facts analysis such as data reduction, data display and conclusion drawing/verification (Hesse, Glenna, Hinrichs, Chiles, \& Sachs, 2019). During the data reduction stage, a content material appraisal was performed to unearth the fundamental knowledge and concept of the researchers at the case universities and those, which are, involved with university spinoffs activities. Consequently, we coded and categorized the facts that were gathered through the interviews based on the themes for analysis (Braun \& Clarke, 2019). The themes were identified based wholly on the number of words and/or issues raised by the respondents. These issues or words were given specific codes for analysis purposes (Braun \& Clarke, 2020). After the completion of the coding, the subject matter identified from the interview scripts were grouped for that reason. The 
INTERNATIONAL JOURNAL OF ACADEMIC RESEARCH IN ACCOUNTING, FINANCE AND MANAGEMENT SCIENCES

Vol. 11, No. 1, 2021, E-ISSN: 2225-8329 @ 2021 HRMARS

interview facts were used to assist document evidence in making assumptions and explanation of the findings (Elliott, 2018).

\section{Data Analysis}

The study used qualitative approach for collecting primary data to explore the existing conditions involving the use of crowdfunding as alternate funding for university spinoff formation and operations in Ghana. The limitation of literature in this area of study particularly in Ghana, called for the adoption of this strategy. The study is an exploratory empirical study, which aims at developing the evidence that crowdfunding, can be an alternate source funding for university spinoff formation. The method is adopted because lack of adequate funding is a major hindrance to commercialisation of innovations in most developing countries. There is therefore the need to adopt a new approach for their funding streams (Elliott, 2018). The study involves conducting semi-structured interviews to gain comprehensive understanding of the topic understudy (Hesse et al., 2019). The study therefore describes the qualitative analysis of the data and also considered the practical steps involved in the analysis. The data for the study is analyzed into themes and sub-themes (Braun \& Clarke, 2006). These generative themes were considered on the bases of how they overlap and how they are related to each other (Braun \& Clarke, 2020). During the process, care was taken to make sure there is proper understanding of the data and making some sense out of it. In terms of data, transcription process and coding, the data unfolds patterns of expressions which, gave clues of divergent or similar themes were identified (Hesse et al., 2019).

\section{Findings and Discussions}

One key finding of the study and perhaps even more of concern is that there is limited interaction between the stakeholders within the quadruple helix (academia, state, industry and the community) and this is affecting the development of innovation. Specifically, there is a lack of common goal and interest among the stakeholders and this is affecting the development of innovation. This notwithstanding, there is evidence to suggest that there is some level of collaboration between the state and academia albeit limited. The collaboration is limited and thereby not impacting positively on the commercialization of innovation. Evidence also shows that there is a minimal collaboration between industry and academia; however, it is not significant enough to make any impact. Furthermore, ample evidence from the data also revealed that CF could be an alternate source of funding for the universities to support the formation of USOs. The evidence suggests that the Ghanaian public will readily accept CF because it is similar to Susu, which is an accepted form of funding raising concept in Ghana. CF is similar to Susu in every sense except in the area of platforms used in accessing these funds. Even though CF is a new concept in the Ghanaian context and there is a lack of awareness of it as a source of raising fund for startup capital, the academic staff are passionate to contribute to any CF to support innovation when the platform is created for them. 
INTERNATIONAL JOURNAL OF ACADEMIC RESEARCH IN ACCOUNTING, FINANCE AND

MANAGEMENT SCIENCES

Vol. 11, No. 1, 2021, E-ISSN: 2225-8329 ๑ 2021 HRMARS

Table 1: Aggregate of number of times themes were mentioned across all interviews

\begin{tabular}{|c|c|c|}
\hline Themes & $\begin{array}{l}\text { Number of times theme was } \\
\text { mentioned (aggregate cross all } \\
\text { interviews) }\end{array}$ & $\begin{array}{l}\text { Number of participants } \\
\text { that mentioned it }\end{array}$ \\
\hline $\begin{array}{l}\text { Theme } \\
\text { Helix) } \\
\text { Sub Themes } \\
\text { i. } \quad \text { academia } \\
\text { ii. state } \\
\text { iii. industry } \\
\text { iv. community }\end{array}$ & $\begin{array}{l}68 \\
41 \\
39 \\
24 \\
20\end{array}$ & $\begin{array}{l}18 \\
19 \\
14 \\
13 \\
11\end{array}$ \\
\hline $\begin{array}{l}\text { Theme 2-Funding } \\
\text { Sub Themes } \\
\begin{array}{ll}\text { i. } \quad \text { funding challenge } \\
\text { ii. } \quad \text { alternate funding }\end{array}\end{array}$ & $\begin{array}{l}83 \\
36 \\
22\end{array}$ & $\begin{array}{l}18 \\
14 \\
14\end{array}$ \\
\hline $\begin{array}{l}\text { Theme } 3 \text { - Crowdfunding } \\
\text { Sub Theme } \\
\text { i. As an alternate }\end{array}$ & $\begin{array}{l}68 \\
22\end{array}$ & $\begin{array}{l}21 \\
14\end{array}$ \\
\hline $\begin{array}{l}\text { Theme 4- USO Formation } \\
\text { Sub Theme } \\
\text { i. factors }\end{array}$ & $\begin{array}{l}125 \\
24\end{array}$ & $\begin{array}{l}21 \\
15\end{array}$ \\
\hline
\end{tabular}

\section{Aggregation of mentioning of themes across all interviews}

A much more systematic approach to support this finding is presented in Table 1, which shows the aggregation of number of times themes were mentioned across all interviews during the data gathering process. As indicated in the table during the interviewing process, 18 participants mentioned collaboration 62 times across all interviews most of which are of negative inferences. Comparatively, about $90 \%$ of the participants think there is a limited collaboration between the universities and other stakeholders in the helix. Nineteen (19) participants think there is a form of collaboration between academia and the state, while fourteen participants think otherwise (McAdam, Miller, \& McAdam, 2018). Only eleven (11) participants were of the view that there is a form of collaboration between academia and the community (Carayannis \& Campbell, 2019b; Prainsack, 2012). The next lowest figure per mentioning is industry, which also has minimal collaboration with academia. The community ranked at bottom as the sub-theme with the lowest figure in terms of mentioning across all interviews.

\section{Theme 1 - Collaboration (Quadruple Helix)}

Consistent with theoretical argument, it is a widely held view that the Quadruple Helix model is centered on the idea of the coming together of academia, government, industry and societal based innovation users to foster innovation and economic prosperity (Kolehmainen et al., 2016). 
INTERNATIONAL JOURNAL OF ACADEMIC RESEARCH IN ACCOUNTING, FINANCE AND MANAGEMENT SCIENCES

Vol. 11, No. 1, 2021, E-ISSN: 2225-8329 @ 2021 HRMARS

Interestingly, the concept of crowdfunding is related to the model because innovation involves the interaction between organizations, individuals, communities and the government (Belleflamme et al., 2014). Accordingly, the study integrates one main underpinning theory, which is Quadruple Helix Innovative theory to develop the research framework, which is shown in Figure 1. This theory was chosen because it considers the fact that adequate interaction between the helices will enhance knowledge based activities in Ghana, which will advance scientific innovation. It will also make available to the Ghanaian public knowledge that could be used to improve the quality of life of the people (Miller et al., 2018). The study therefore explored the concepts of Quadruple Helix framework and its relevance to university spinoffs and crowdfunding.

\section{Sub themes- Relationships between helices}

The findings from the data appear to support the assumption that crowdfunding is a dependable way for university spinoffs to raise funds from unlimited groups of people within the helices to enable them commercialize their innovations. A reasonable approach to tackle the problem therefore is to rely on the community as a major source of funding for the other stakeholders in the helix. (Carayannis et al., 2012). The study therefore aligns with the propositions developed in the quadruple helix theory because it is consistent with the main proposition of the study, which is that university spinoffs serve as a vital link between academia and the community, which are stakeholders in the helix. Academia is capable of establishing university spinoffs which can boost economic growth by creating employment which is knowledge-based and improves the growth capacity of a region, (Clausen and Rasmussen, 2013; Ramaciotti and Rizzo, 2015).

However, as demonstrated in Figure 1 (which is the conceptual framework), the findings suggest that there is very little interaction between the stakeholders of the helix in Ghana. There is some level of interaction between the state and the universities. These interactions come in the form of the state providing funding support in the form of budgetary allocations and subventions. The state also provides some level of funding to support research (Atuahene, 2015). However, very little effort is made on the part of the state to assist the universities to commercialize innovation (Carayannis \& Campbell, 2019a). As indicated again in Figure 1, there is an achievable collaboration between the universities and industry. However, there is a minimal collaboration between the universities and the community (Kuma, Effandi, Yusoff, \& Kuma, 2021).

Likewise, some industry players somehow provide minimal support to academia. This is only limited to provision of academic facilities and to some extent, support for support research in terms of providing laboratories (Muparadzi \& Caesar, 2020). Nevertheless, when it comes to providing funding support for the commercialisation of innovation, the impact is minimal. Even within the university setting itself, there is lack of cohesion, collaboration and teamwork among the staff in the area of research and innovation (Okebukola, 2015). The universities themselves have in place certain policies that are hindrances to the development of innovation, for example, the promotions of university staff are based on research publications in scientific journals. This practice is not popular with staff with TVET background. 


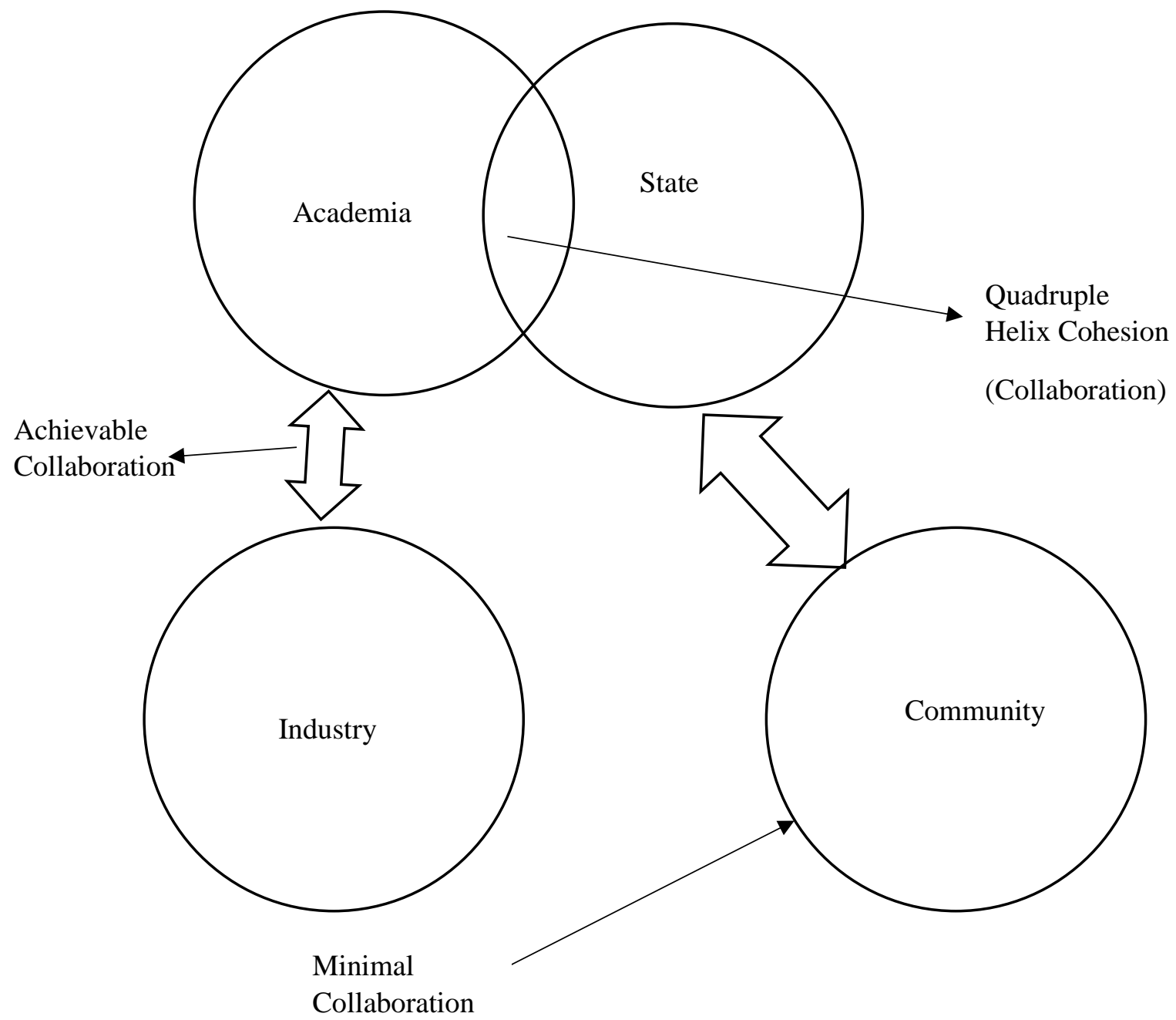

Figure 1: Quadruple Helix Model as it pertains in Ghana, Academia + State- Industry Community

\section{Academia and other Helices}

To substantiate our analysis, we further present our findings in a graphical form, which is shown in Figure 2, which is a thematic framework for quadruple helix. We sought to demonstrate the level of interaction between the stakeholders in the helix in terms of their involvement in the commercialization of innovation. The findings as shown in the graph indicates that, academia is virtually operating on its own without co-opting the other members of the helix in the innovation process (Prainsack, 2012). Academia is $7 \%$ self-reliance with a little over $2 \%$ support from the state. However, the industry and the community are relegated to the background with minimum contributions to knowledge dissemination. The role of the community is elaborated further in the next section. 


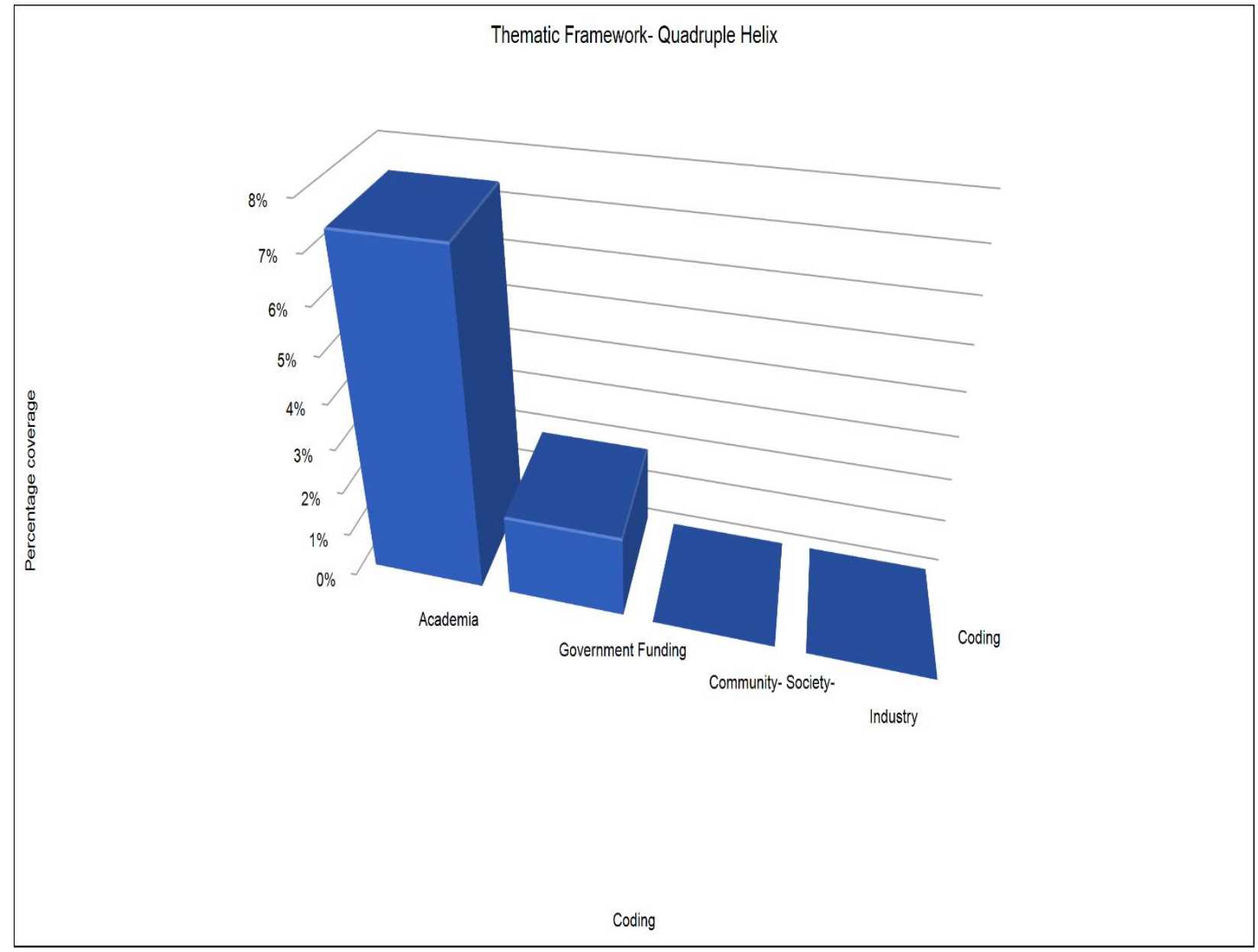

Figure 2: Contributions from stakeholders from Helix

\section{Relationship between Academia and Community}

Our paper proceeds by further exploring the role of the community in the commercialization of innovation. Specifically, we find evidence to suggest that the contributions of the community in developing innovation is quite insignificant (Kolehmainen et al., 2016). The community is a standalone entity/stakeholder in the helix. This is because the other three stakeholders of the helix are not interacting with the community (Galvão et al., 2017). This assertion is demonstrated via the conceptual Framework of the study, which is Figure 1. Meanwhile, there is an achievable relation between academia and the community, which is yet to be exploited by the sampled universities.

Our findings advance a general approach that the inability of the universities to involve the community in their activities results in the low patronage of their products leading to failure in the performance of the products on the market. In addition, the universities do not approach the community for funding support for the commercialization of innovation (McAdam et al., 2018). Therefore, it is of the utmost importance for the universities to make conscious efforts to involve the community in their activities (Hui, Greenberg, \& Gerber, 2014). We therefore argue that the community has a vital role in the helix in terms of providing funding support and patronage of 
INTERNATIONAL JOURNAL OF ACADEMIC RESEARCH IN ACCOUNTING, FINANCE AND

MANAGEMENT SCIENCES

Vol. 11, No. 1, 2021, E-ISSN: 2225-8329 @ 2021 HRMARS

innovative products, so, the other three stakeholders need to involve the community (Prainsack, 2012).

\section{Theme 2 - Thematic Framework on Funding}

In this subsection, we provided an overview of the funding streams of the sampled universities and explored how it impedes or enhances university spinoff formation. Our findings show that even though there are many factors that impede the formation of university spinoff, lack of funding ranked as the number one challenge. The funding support received by the universities from government is not sufficient to warrant commercialization of innovation (Atuahene, 2015). Specifically, as captured in Table 1 (the aggregation of mentioning across all interviews), funding was mentioned 83 times across all interviews by 18 participants. At the same time, funding challenges was mentioned 36 times across all interviews. The aggregation of these two figures results in 119 mentioning of funding across all interviews. This finding gives weight to the fact that lack of funding is top on the list of needs for the universities.

Specifically, our findings suggest that the main sources of funding of the universities is from the government and proceeds from their own business initiatives or other internally generated funds (Bingab, Forson, Mmbali, \& Baah-Ennumh, 2016). In a number of significant ways, these streams of funding are insufficient compared to the demand on their resources. Consequently, there is a strain on their funds, creating a funding gap for expanding their activities. In view of this, there is therefore the need to take this pressure off their sources of funding by exploring an alternate source of funding. Overall, reviewed data, as captured in Table 1, suggest that there is the need for alternate source of funding to augment funding streams for the universities (Muparadzi \& Caesar, 2020). Information from the table indicates that 14 respondents expressed their views in relation to that effect. Consequently, the sub theme alternate funding was mentioned 22 times across all interviews. These mentions were all in relation to the universities adopting alternate funding to solve the challenges that confront them, thereby preventing them from establishing university spinoffs. In addition, as shown in NVivo word cloud in Figure 3, among all the coded nodes, funding is more conspicuous (Alam, 2020). This is an indication that funding is a major factor confronting the universities and this is thereby preventing them from establishing university spinoff.

Perhaps, of even more concern is the fact that the few innovative ideas that have been developed by the university staff in the case universities remain at their workshops without them being commercialized. The idea behind non-commercialization of such innovative products is premised on the thinking that the universities are not established to run businesses. Their core mandate is teaching and learning. Based on this premise, academia in Ghana engages more in teaching with very little attention given to research and innovation. Further, the state shows little interest in research and innovation coming out from the academic institutions. Therefore, the state, which is a stakeholder in the helix, does not provide startup capital to the academic institutions to establish university spinoffs. 


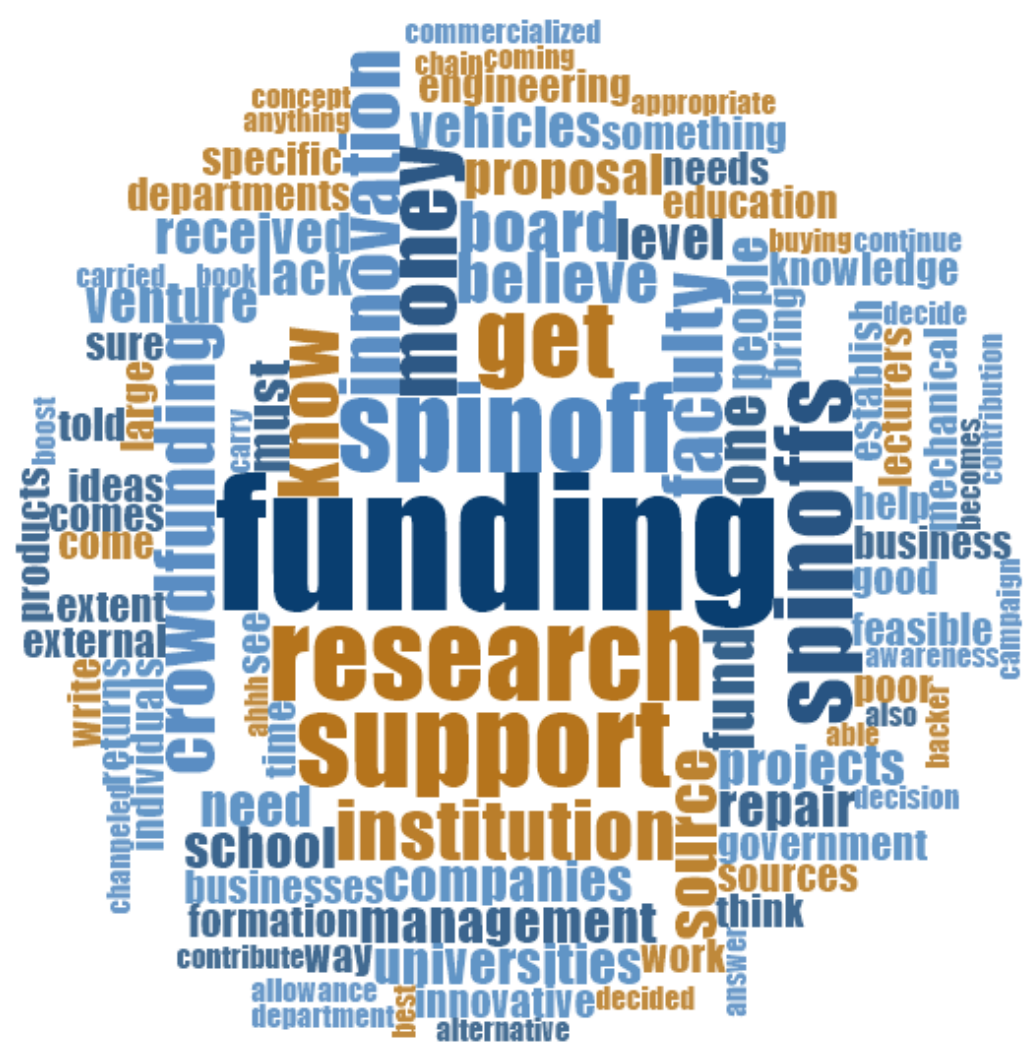

Figure 3: NVivo Word cloud show the prominence of funding

Theme 3 - Thematic Framework on Crowdfunding

Although we have discussed other funding streams available to the universities in terms of commercialization of innovation, our aim is to suggest crowdfunding as an alternate finance to address their funding gap. In this section, we lay out the key findings in that regard based on analyzed data.

During the interview, participants admitted they were not aware of any crowdfunding platforms or any policy regulation supporting crowdfunding activities in the country. They also admitted they have not crowdfunded or tried any form of crowdfunding; however, they have tried other forms of fundraising to support their activities. These forms of fundraising have some semblance or similarities with crowdfunding (Lei, Yayla, \& Kahai, 2018). Even though there are some few Ghanaian based crowdfunding platforms such as MyaidFund, Myneesh, NUNA, Pesewa etcetera operating in Ghana, the respondents are not aware of such platforms (Iddris, 2019). In addition, there are other Ghanaian based campaigns launched on foreign crowdfunding platforms such as Kickstarter, IndieGoGo etcetera which have crowdfunded community based projects such as schools and hospitals (Colistra \& Duvall, 2017).

The above notwithstanding, evidence from the data shows that majority of the participants are willing to back any form of crowdfunding campaign, which is geared towards commercialization of innovation provided they would receive any reward/ dividend on their contributions. For that reason, Equity and Peer-to-Peer (P2P) crowdfunding will thrive better in Ghana than the Donation and 
INTERNATIONAL JOURNAL OF ACADEMIC RESEARCH IN ACCOUNTING, FINANCE AND MANAGEMENT SCIENCES

Vol. 11, No. 1, 2021, E-ISSN: 2225-8329 @ 2021 HRMARS

Reward based crowdfunding (Kuppuswamy \& Bayus, 2013; Mollick, 2014). Nonetheless, both Donation and Reward based crowdfunding will be acceptable by the Ghanaian public (Crowd) because of the existence of social media platforms such as WhatsApp, Facebook etc.

These social media platforms have created conducive platforms for social groups to raise funds in support of startup capital for their group members and for community projects within the Ghanaian context (Kuma, Miencha, Abrahams, \& Boadi, 2017). The phenomenon is more prevalent among old students associations and community groups. The Ghanaian public has some attachment to their old secondary schools and colleges and are prepared to launch crowd fundraising campaigns in support of projects in their alma maters. However, some of the respondents raised concerns about the fraud elements that comes with such fund raising campaigns (Musara \& Nieuwenhuizen, 2020). These concerns can be addressed by the state putting in place policies and regulations that will prevent crowdfunding platforms from defrauding project backers. The Thematic Framework in Figure 4 is used to illustrate this argument.

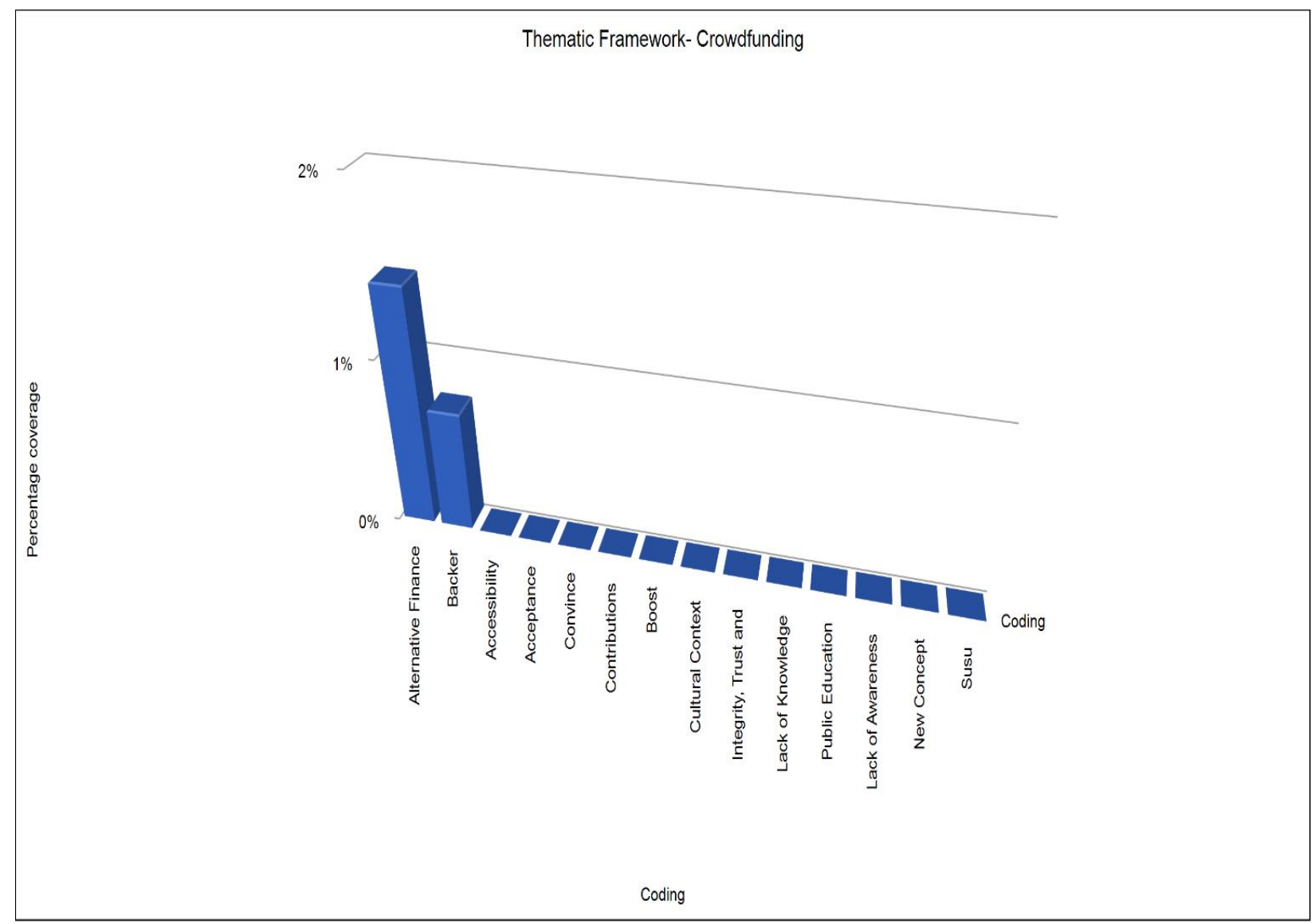

\section{Figure 4: Crowdfunding Thematic Framework}

\section{Sub-theme - Crowdfunding as Alternate Funding}

Furthermore, Table 1 revealed that the participants see crowdfunding as a dependable alternate funding source. Crowdfunding was mentioned 68 times across all interviews. Unlike all the other themes and sub themes, crowdfunding is the only theme that has all the 21 participants expressing their willingness to support it as a means of fundraising in support of university spinoff formation. 
INTERNATIONAL JOURNAL OF ACADEMIC RESEARCH IN ACCOUNTING, FINANCE AND MANAGEMENT SCIENCES

Vol. 11, No. 1, 2021, E-ISSN: 2225-8329 @ 2021 HRMARS

Figure 5 further demonstrates importance of crowdfunding in the quest of university spinoff formation by the universities. It shows the relationship between the themes and sub themes in the scheme of things. It shows a symmetrical relationship between university spinoff and funding streams. A similar relationship is indicated between commercialisation and funding streams. On the other hand, the relationship between funding streams and crowdfunding is associative. This confirms the finding that crowdfunding is a dependable alternative to other sources of funding available to these institutions.

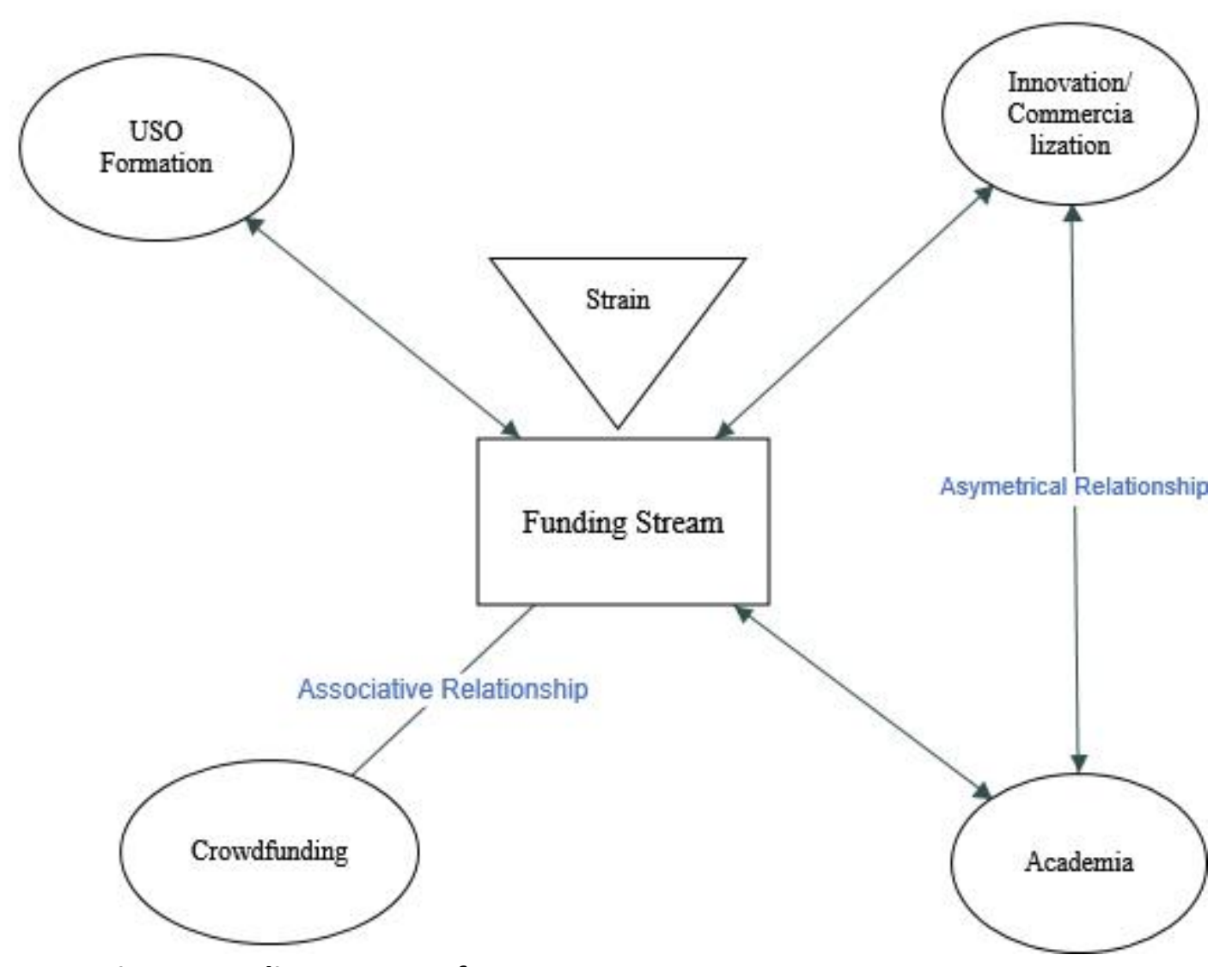

Figure 5: Strain on Funding Streams for USOs

\section{Theme 4: Spinoff formation}

The findings suggest that the academia in Ghana, which is supposed to be the cradle of knowledge dissemination is playing a very limited role in university spinoff formation in the country (Carayannis \& Campbell, 2019b). Academic staff with innovative ideas receive little support from management of their respective universities (Kiggundu, 1991). Consequently, the universities stifle commercialization of innovation by not providing the needed financial support as well as conducive atmosphere. They are unable to provide basic equipment to enhance research and innovation.

The data also indicates that one factor that acted as a hindrance to the formation of university spinoffs in the case universities is the gestation periods for forming university spinoffs. The length of time involved in university spinoffs formation deter investors particularly in Ghana. This is because of the unstable nature of the Ghanaian currency, which could affect investors' return on investments. The situation therefore demotivate venture capitalists in Ghana to invest their money into 
INTERNATIONAL JOURNAL OF ACADEMIC RESEARCH IN ACCOUNTING, FINANCE AND MANAGEMENT SCIENCES

Vol. 11, No. 1, 2021, E-ISSN: 2225-8329 @ 2021 HRMARS

commercialization of innovations. Coupled with that is the unfavourable nature of the patent law in Ghana. The law gives the patent right to the universities because they fund it. This has culminated in low-level interest from the academic staff.

\section{University Spinoff for sachet or pure water}

Specifically, the study find evidence to support the fact that out of the three case universities, only one of them has established university spinoff, which produces filtered water, packaged in sachets. It is branded as sachet or pure water in the local parlance (Stoler, Tutu, \& Winslow, 2015). The university spinoff was established from staff innovative initiatives that led to the development of a machine that could produce the sachet water in commercial quantities for the local market. The drive for establishing the sachet water manufacturing spinoff was because there is ready market for it. The water is supposed to be supplied to neighboring communities. In addition, the student community as well as staff of the university also served as a ready market for the product. The university has a student population of over 5000 and staff population of over 400. Most households in Ghana depend largely on sachet water because tap water flowing to many homes and communities is impure (Addo, Amankwaa, \& Gyasi, 2019; Stoler et al., 2015). In fact, sachet water is a product, which is highly patronized by the Ghanaian public because of the hot nature of the climate (Morinville, 2017). It is affordable and hawkers sell them in moving traffic at road intersections (Stoler et al., 2012).

However, the university spinoff does not have the autonomy it requires to operate as an independent entity. It operates under the same bureaucratic system of the university where the decision process has to pass through a very lengthy process. The situation affects the smooth running of the university spinoff as a viable business venture (Mathisen \& Rasmussen, 2019). In addition, there was low patronage of the product because it could not compete favourably with similar brands on the market. The situation led to product failure thereby making the university spinoff redundant.

\section{Thematic framework For Autonomy}

To facilitate our exploration of the thematic framework on autonomy, we depended on seven main sub-themes or subcategories which we presented in Figure 6 based on views expressed by participants (Braun \& Clarke, 2020). The figure presented in percentage terms the weight given to some sub-themes by the participants regarding the challenges they faced in their business units, incubation centers and university spinoffs (Muscio, Quaglione, \& Ramaciotti, 2016).

In percentage terms, autonomy ranked high at $28 \%$ on the list of challenges encountered by the unit heads. Overall, the evidence emerging suggests there is too much interference in the running of the business units and incubation centers of all three case universities. The universities are unwilling to wean their business units from central control, thereby slowing down the decision process of these units. In addition, the units do not have financial autonomy as well as operational autonomy (Civera, Donina, Meoli, \& Vismara, 2019). The control mechanism put in place by central administration prevents the units from being run as separate entities.

In a number of significant ways, the use of localized materials and product development also have high ratings of $7 \%$ respectively. Indeed, there is evidence to suggest the failure of the case universities to use local raw materials affect product developments (Soetanto \& Van Geenhuizen, 2015). The use of local raw materials could result in the production of affordable products that could compete favourably on the local market. Coupled with that is low patronage of products from the business units because consumers consider them as of low quality. The situation is such that even students 
INTERNATIONAL JOURNAL OF ACADEMIC RESEARCH IN ACCOUNTING, FINANCE AND

MANAGEMENT SCIENCES

Vol. 11, No. 1, 2021, E-ISSN: 2225-8329 @ 2021 HRMARS

and the university community are unwilling to patronize their own products. Product quality needs to be improved to be able to compete favourably on the open market.

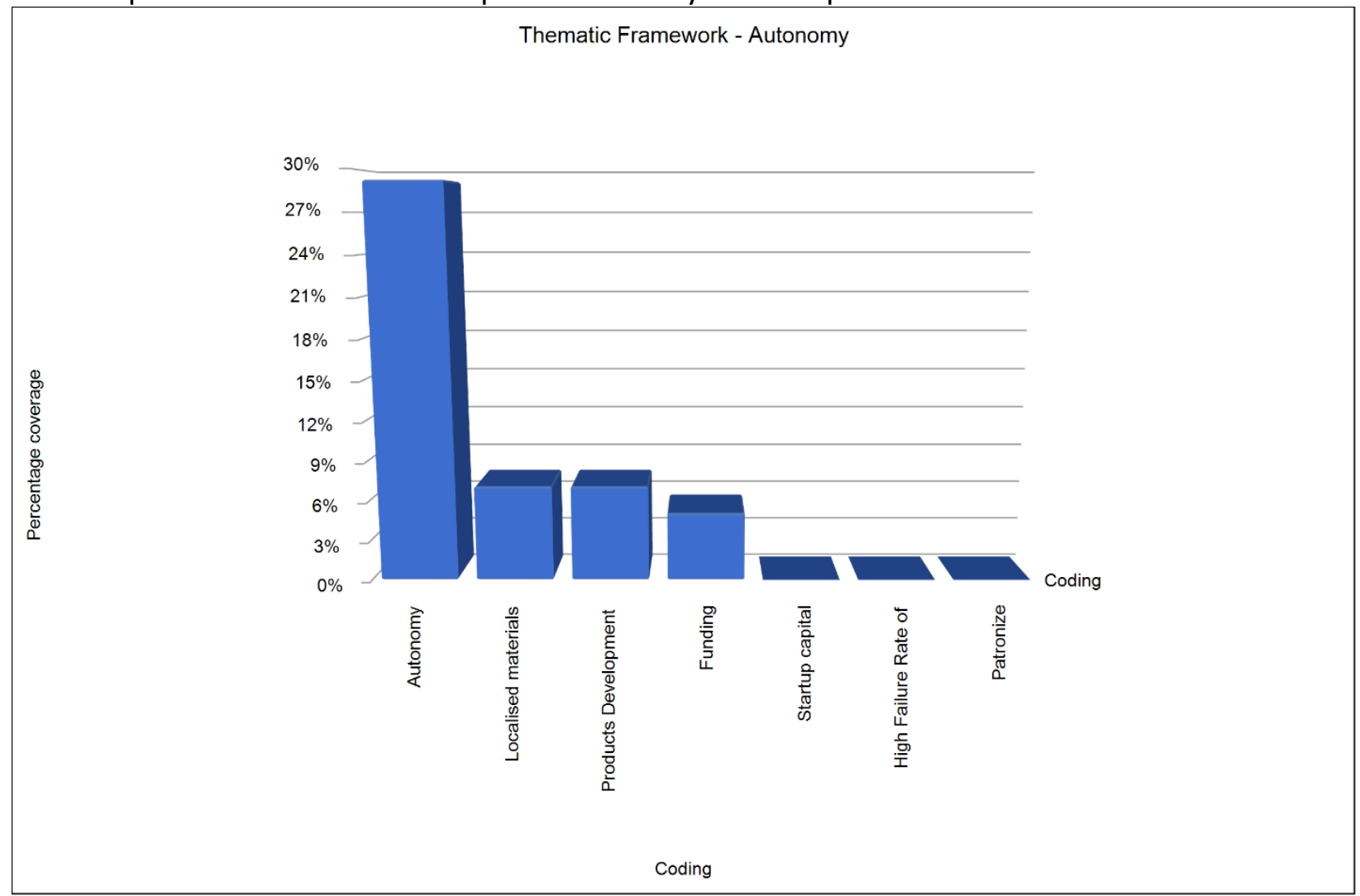

Figure 6: Thematic Framework- Autonomy

\section{Drawback of Quadruple Helix Theory}

The finding is at variance with existing literature on the quadruple helix theory because there are some contradictions in the application of the theory in the Ghanaian context. This argument applies to the fact that the theory did not attempt to quantify the interaction between the helices outside the American or European context. The contradictions in the application of the quadruple helix theory, comparative to prevailing situation among the helices in Ghana could be attributed to existing factors, which are peculiar to Ghana and this is not duly recognized by the model. For instance, the high poverty rate in Ghana means members of the community are incapable of making any meaningful financial contribution to the development of innovation in the Ghanaian context (Abebe, Tekleab, \& Lado, 2020). Coupled with that is the high illiteracy rate, which makes it virtually impossible for the community to play any meaningful role as a dependable stakeholder in the helix.

\section{Conclusions}

In this study, we empirically explored the funding gaps that threaten the formation and operations of university spinoffs in Ghana. We also discussed crowdfunding as an alternative funding to address these financial gaps using the quadruple helix model of innovation. Centered upon these specifics, we combined theoretical perspectives of the quadruple helix model with the practical aspects of university spinoffs raising finance from the community (crowd). We also analytically appraised the role of the community (crowd) in providing startup capital to the academia to commercialize their 
INTERNATIONAL JOURNAL OF ACADEMIC RESEARCH IN ACCOUNTING, FINANCE AND

MANAGEMENT SCIENCES

Vol. 11, No. 1, 2021, E-ISSN: 2225-8329 @ 2021 HRMARS

inventions. Consequently, there is the need for a closer partnership between the stakeholders in the quadruple helix to commercialize innovation leading to knowledge spillover to local communities in Ghana. (McAdam, Miller, \& McAdam, 2016)(McAdam, Miller, \& McAdam, 2016)(McAdam <i>et al. $</ i>$, 2016) By conducting this study, we contributed to literature by empirically proving and aligning with a small number of scholars that crowdfunding can be a dependable source of finance for university spinoff formation particularly in African countries. This will help the African continent to develop its own prototype of knowledge management and high-tech development processes.

\section{References}

Abebe, M. A., Tekleab, A. G., \& Lado, A. A. (2020). Introduction: Special issue on multilevel perspectives on leadership in the African context. Africa Journal of Management, 1-16. https://doi.org/10.1080/23322373.2020.1779575

Addo, B. E., Amankwaa, G., \& Gyasi, R. M. (2019). Physicochemical and bacteriological quality of sachet water used by ghanaian university students: Implications for public health. Journal of Water Sanitation and Hygiene for Development, 9(1), 56-63. https://doi.org/10.2166/washdev.2019.109

Alam, M. K. (2020). A systematic qualitative case study: questions, data collection, NVivo analysis and saturation. Qualitative Research in Organizations and Management: An International Journal. https://doi.org/10.1108/QROM-09-2019-1825

Atuahene, F. (2015). Higher Education Finance in Ghana. International Higher Education, (50). https://doi.org/10.6017/ihe.2008.50.7996

Bingab, B. B. B., Forson, J. A., Mmbali, O. S., \& Baah-Ennumh, T. Y. (2016). The evolution of university governance in Ghana: Implications for education policy and practice. Asian Social Science, 12(5), 147-160. https://doi.org/10.5539/ass.v12n5p147

Braun, V., \& Clarke, V. (2006). Using thematic analysis in psychology. Qualitative Research in Psychology, 3(2), 77-101. https://doi.org/10.1191/1478088706qp063oa

Braun, V., \& Clarke, V. (2019). Reflecting on reflexive thematic analysis. Qualitative Research in Sport, Exercise and Health, 11(4), 589-597. https://doi.org/10.1080/2159676X.2019.1628806

Braun, V., \& Clarke, V. (2020). One size fits all? What counts as quality practice in (reflexive) thematic analysis? Qualitative Research in Psychology, 00(00), 1-25.

https://doi.org/10.1080/14780887.2020.1769238

Carayannis, E. G., \& Campbell, D. F. J. (2019a). Innovation Systems in Conceptual Evolution: Mode 3 Knowledge Production in Quadruple and Quintuple Helix Innovation Systems. (1945), 39-49. https://doi.org/10.1007/978-3-030-01517-6_5

Carayannis, E. G., \& Campbell, D. F. J. (2019b). Mode 1, Mode 2, and Mode 3: Triple Helix and Quadruple Helix. 17-30. https://doi.org/10.1007/978-3-030-01517-6_3

Choy, K., \& Schlagwein, D. (2016). Crowdsourcing for a better world: On the relation between IT affordances and donor motivations in charitable crowdfunding. Information Technology and People, 29(1), 221-247. https://doi.org/10.1108/ITP-09-2014-0215

Civera, A., Donina, D., Meoli, M., \& Vismara, S. (2019). Fostering the creation of academic spinoffs: does the international mobility of the academic leader matter? International Entrepreneurship and Management Journal. https://doi.org/10.1007/s11365-019-00559-8

Civera, A., Meoli, M., \& Vismara, S. (2017). Policies for the Provision of Finance to Science-based Entrepreneurshipy. In Annals of Science and Technology Policy (Vol. 1). 
INTERNATIONAL JOURNAL OF ACADEMIC RESEARCH IN ACCOUNTING, FINANCE AND

MANAGEMENT SCIENCES

Vol. 11, No. 1, 2021, E-ISSN: 2225-8329 @ 2021 HRMARS

https://doi.org/10.1561/110.00000004

Colistra, R., \& Duvall, K. (2017). Show Me the Money : Importance of Crowdfunding Factors on Backers 'Decisions to Financially Support Kickstarter Campaigns.

https://doi.org/10.1177/2056305117736942

Dzisah, J., \& Etzkowitz, H. (2008). Triple helix circulation: the heart of innovation and development. International Journal of Technology Management and Sustainable Development, 7(2), 101-115. https://doi.org/10.1386/ijtm.7.2.101_1

Elliott, V. (2018). Thinking about the coding process in qualitative data analysis. Qualitative Report, 23(11), 2850-2861.

Ferri, S., Fiorentino, R., Parmentola, A., \& Sapio, A. (2019). Patenting or not? The dilemma of academic spin-off founders. Business Process Management Journal, 25(1), 84-103. https://doi.org/10.1108/BPMJ-06-2017-0163

Fini, R., Rasmussen, E., Siegel, D., \& Wiklund, J. (2018). Rethinking the commercialization of public science: From entrepreneurial outcomes to societal impacts. Academy of Management Perspectives, 32(1), 4-20. https://doi.org/10.5465/amp.2017.0206

Galvão, A., Mascarenhas, C., Rodrigues, G. R., Marques, C. S., \& Leal, C. T. (2017). A quadruple helix model of entrepreneurship, innovation and stages of economic development. Review of International Business and Strategy, 27(2), 261-282. https://doi.org/10.1108/RIBS-01-20170003

Hesse, A., Glenna, L., Hinrichs, C., Chiles, R., \& Sachs, C. (2019). Qualitative Research Ethics in the Big Data Era. American Behavioral Scientist, 63(5), 560-583.

https://doi.org/10.1177/0002764218805806

Hui, J. S., Greenberg, M. D., \& Gerber, E. M. (2014). Understanding the role of community in crowdfunding work. Proceedings of the ACM Conference on Computer Supported Cooperative Work, CSCW, 62-74. https://doi.org/10.1145/2531602.2531715

Iddris, F. (2019). The Role of Crowdfunding in Promoting Innovation in Microenterprises in Africa. UCC Conference, (February), 1-14.

Kiggundu, M. N. (1991). The Challenges of Management Development in Sub-Saharan Africa. Journal of Management Development, 10(6), 32-47. https://doi.org/10.1108/02621719110004411

Kolehmainen, J., Irvine, J., Stewart, L., Karacsonyi, Z., Szabó, T., Alarinta, J., \& Norberg, A. (2016). Quadruple Helix, Innovation and the Knowledge-Based Development: Lessons from Remote, Rural and Less-Favoured Regions. Journal of the Knowledge Economy, 7(1), 23-42. https://doi.org/10.1007/s13132-015-0289-9

Kuma, F. K., Effandi, M., Yusoff, B., \& Kuma, F. K. (2021). Resolving Information Asymmetric and Social Network Theories Challenges in Crowdfunding Campaigns . Resolving Information Asymmetric and Social Network Theories Challenges in Crowdfunding Campaigns . 1(4), 89-102. https://doi.org/10.6007/IJARBSS/v11-i4/9628

Kuma, F. K., Miencha, I., Abrahams, A. Y., \& Boadi, R. N. (2017). The Impact of Mobile Money Services on the Financial Transactions of Tertiary Students. International Journal of Innovative Research and Development, 6(7). https://doi.org/10.24940/ijird/2017/v6/i7/jul17082

Kuppuswamy, V., \& Bayus, B. L. (2013). Crowdfunding creative ideas: the dynamics of projects backers in kickstarter. SSRN Working Paper Series.

Smith, L. H., \& Ho, K. (2006). Measuring the performance of Oxford University, Oxford Brookes University and the government laboratories' spin-off companies. Research Policy, 35(10), 1554- 
INTERNATIONAL JOURNAL OF ACADEMIC RESEARCH IN ACCOUNTING, FINANCE AND

MANAGEMENT SCIENCES

Vol. 11, No. 1, 2021, E-ISSN: 2225-8329 @ 2021 HRMARS

1568. https://doi.org/10.1016/j.respol.2006.09.022

Lei, Y., Yayla, A., \& Kahai, S. (2018). Unique Challenges of Decision-Making Process on Crowdfunding Platforms - An Exploratory Study. Proceedings of the 51st Hawaii International Conference on System Sciences, 9, 1809-1817. https://doi.org/10.24251/hicss.2018.228

Lockett, A., Siegel, D., Wright, M., \& Ensley, M. D. (2005). The creation of spin-off firms at public research institutions: Managerial and policy implications. Research Policy, 34(7), 981-993. https://doi.org/10.1016/j.respol.2005.05.010

Lockett, A., \& Wright, M. (2005). Resources, capabilities, risk capital and the creation of university spin-out companies. Research Policy, 34(7), 1043-1057.

https://doi.org/10.1016/j.respol.2005.05.006

Mathisen, M. T., \& Rasmussen, E. (2019). The development, growth, and performance of university spin-offs: a critical review. In Journal of Technology Transfer. https://doi.org/10.1007/s10961018-09714-9

McAdam, M., Miller, K., \& McAdam, R. (2016). Situated regional university incubation: A multi-level stakeholder perspective. Technovation, 50-51, 69-78.

https://doi.org/10.1016/j.technovation.2015.09.002

McAdam, M., Miller, K., \& McAdam, R. (2018). Understanding Quadruple Helix relationships of university technology commercialisation: a micro-level approach. Studies in Higher Education, 43(6), 1058-1073. https://doi.org/10.1080/03075079.2016.1212328

Mollick, E. (2014). The dynamics of crowdfunding: An exploratory study. Journal of Business Venturing, 29(1), 1-16. https://doi.org/10.1016/j.jbusvent.2013.06.005

Morinville, C. (2017). Sachet water: regulation and implications for access and equity in Accra, Ghana. Wiley Interdisciplinary Reviews: Water, 4(6), e1244. https://doi.org/10.1002/wat2.1244

Muparadzi, A., \& Caesar, L. D. (2020). Examining the dynamics of industry-university collaborations in Ghana. Journal of Applied Research in Higher Education. https://doi.org/10.1108/JARHE-032020-0064

Musara, M., \& Nieuwenhuizen, C. (2020). Informal sector entrepreneurship, individual entrepreneurial orientation and the emergence of entrepreneurial leadership. Africa Journal of Management, 1-20. https://doi.org/10.1080/23322373.2020.1777817

Muscio, A., Quaglione, D., \& Ramaciotti, L. (2016). The effects of university rules on spinoff creation: The case of academia in Italy. Research Policy, 45(7), 1386-1396. https://doi.org/10.1016/j.respol.2016.04.011

Okebukola, P. A. (2015). Towards Innovative Models for Funding Higher Rducation in Africa. Association of African Universities, pp3-10.

Prainsack, B. (2012). Elias G. Carayannis and David F. J. Campbell, Mode 3 Knowledge Production in Quadruple Helix Innovation Systems: 21st-Century Democracy, Innovation, and Entrepreneurship for Development. Minerva, 50(1), 139-142. https://doi.org/10.1007/s11024012-9194-6

Ramaciotti, L., \& Rizzo, U. (2015). The determinants of academic spin-off creation by Italian universities. $R$ and D Management, 45(5), 501-514. https://doi.org/10.1111/radm.12105

Smith, H. L., \& Romeo, S. (2012). Entrepreneurship and innovation: Oxfordshire's high- tech economy - firm survival, growth and innovation. Entrepreneurship, Social Capital and Governance: Directions for the Sustainable Development and Competitiveness of Regions, (May), 27-52. https://doi.org/10.4337/9781781002841.00007 
INTERNATIONAL JOURNAL OF ACADEMIC RESEARCH IN ACCOUNTING, FINANCE AND

MANAGEMENT SCIENCES

Vol. 11, No. 1, 2021, E-ISSN: 2225-8329 @ 2021 HRMARS

Soetanto, D., \& Van Geenhuizen, M. (2015). Getting the right balance: University networks' influence on spin-offs' attraction of funding for innovation. Technovation, 36, 26-38. https://doi.org/10.1016/j.technovation.2014.10.008

Stoler, J., Fink, G., Weeks, J. R., Otoo, R. A., Ampofo, J. A., \& Hill, A. G. (2012). When urban taps run dry: Sachet water consumption and health effects in low income neighborhoods of Accra, Ghana. Health and Place, 18(2), 250-262. https://doi.org/10.1016/j.healthplace.2011.09.020

Stoler, J., Tutu, R. A., \& Winslow, K. (2015). Piped water flows but sachet consumption grows: The paradoxical drinking water landscape of an urban slum in Ashaiman, Ghana. Habitat International, 47, 52-60. https://doi.org/10.1016/j.habitatint.2015.01.009

Valanciene, L., \& Jegeleviciute, S. (2013). VALUATION OF CROWDFUNDING : 18(1), 39-48.

Atuahene, F. (2015) 'Higher Education Finance in Ghana', International Higher Education, (50).

Bingab, B. B. B., Forson, J. A., Mmbali, O. S., and Baah-Ennumh, T. Y. (2016) 'The evolution of university governance in Ghana: Implications for education policy and practice', Asian Social Science, 12(5), pp. 147-160.

Braun, V., and Clarke, V. (2006) 'Using thematic analysis in psychology', Qualitative Research in Psychology, 3(2), pp. 77-101.

Braun, V., and Clarke, V. (2019) 'Reflecting on reflexive thematic analysis', Qualitative Research in Sport, Exercise and Health. Routledge, 11(4), pp. 589-597.

Braun, V., and Clarke, V. (2020) 'One size fits all? What counts as quality practice in (reflexive) thematic analysis?' Qualitative Research in Psychology. Routledge, 00(00), pp. 1-25.

Carayannis, E. G., and Campbell, D. F. J. (2019a) 'Innovation Systems in Conceptual Evolution: Mode 3 Knowledge Production in Quadruple and Quintuple Helix Innovation Systems', (1945), pp. 3949.

Carayannis, E. G. and Campbell, D. F. J. (2019b) 'Mode 1, Mode 2, and Mode 3: Triple Helix and Quadruple Helix', pp. 17-30.

Choy, K., and Schlagwein, D. (2016) 'Crowdsourcing for a better world: On the relation between IT affordances and donor motivations in charitable crowdfunding', Information Technology and People, 29(1), pp. 221-247.

Civera, A., Donina, D., Meoli, M., and Vismara, S. (2019) 'Fostering the creation of academic spinoffs: does the international mobility of the academic leader matter?', International Entrepreneurship and Management Journal. International Entrepreneurship and Management Journal.

Civera, A., Meoli, M., and Vismara, S. (2017) Policies for the Provision of Finance to Science-based Entrepreneurshipy, Annals of Science and Technology Policy.

Colistra, R., and Duvall, K. (2017) 'Show Me the Money : Importance of Crowdfunding Factors on Backers ' Decisions to Financially Support Kickstarter Campaigns'.

Cumming, D., and Hornuf, L. (2018) 'The economics of crowdfunding: Startups, portals and investor behavior', The Economics of Crowdfunding: Startups, Portals and Investor Behavior, pp. 1-283.

Dzisah, J., and Etzkowitz, H. (2008) 'Triple helix circulation: the heart of innovation and development', International Journal of Technology Management and Sustainable Development, 7(2), pp. 101115.

Elliott, V. (2018) 'Thinking about the coding process in qualitative data analysis', Qualitative Report, 23(11), pp. 2850-2861.

Ferri, S., Fiorentino, R., Parmentola, A., and Sapio, A. (2019) 'Patenting or not? The dilemma of academic spin-off founders', Business Process Management Journal, 25(1), pp. 84-103. 
INTERNATIONAL JOURNAL OF ACADEMIC RESEARCH IN ACCOUNTING, FINANCE AND

MANAGEMENT SCIENCES

Vol. 11, No. 1, 2021, E-ISSN: 2225-8329 @ 2021 HRMARS

Fini, R., Rasmussen, E., Siegel, D., and Wiklund, J. (2018) 'Rethinking the commercialization of public science: From entrepreneurial outcomes to societal impacts', Academy of Management Perspectives, 32(1), pp. 4-20.

Galvão, A., Mascarenhas, C., Gouveia Rodrigues, R., Marques, C. S., and Leal, C. T. (2017) 'A quadruple helix model of entrepreneurship, innovation and stages of economic development', Review of International Business and Strategy, 27(2), pp. 261-282.

Hesse, A., Glenna, L., Hinrichs, C., Chiles, R., and Sachs, C. (2019) 'Qualitative Research Ethics in the Big Data Era', American Behavioral Scientist, 63(5), pp. 560-583.

Hui, J. S., Greenberg, M. D., and Gerber, E. M. (2014) 'Understanding the role of community in crowdfunding work', Proceedings of the ACM Conference on Computer Supported Cooperative Work, CSCW, pp. 62-74.

Iddris, F. (2019) 'The Role of Crowdfunding in Promoting Innovation in Microenterprises in Africa', UCC Conference, (February), pp. 1-14.

Kolehmainen, J., Irvine, J., Stewart, L., Karacsonyi, Z., Szabó, T., Alarinta, J., and Norberg, A. (2016) 'Quadruple Helix, Innovation and the Knowledge-Based Development: Lessons from Remote, Rural and Less-Favoured Regions', Journal of the Knowledge Economy, 7(1), pp. 23-42.

Kuppuswamy, V., and Bayus, B. L. (2013) 'Crowdfunding creative ideas: the dynamics of projects backers in kickstarter. SSRN Working Paper Series.'

Kuppuswamy, V., and Bayus, B. L. (2017) 'Does my contribution to your crowdfunding project matter?', Journal of Business Venturing. Elsevier Inc., 32(1), pp. 72-89.

Kuma, K. F., and Yosuff, M. E. (2020) 'Hypothetical Aspect of Crowdfunding as Alternate Finance for University Spinoffs and Quadruple Helix', Journal of Research Management \& Governance, 3(1), pp. 1-17.

Smith, L. H., and Ho, K. (2006) 'Measuring the performance of Oxford University, Oxford Brookes University and the government laboratories' spin-off companies', Research Policy, 35(10), pp. 1554-1568.

Lei, Y., Yayla, A., and Kahai, S. (2018) 'Unique Challenges of Decision-Making Process on Crowdfunding Platforms - An Exploratory Study', Proceedings of the 51st Hawaii International Conference on System Sciences, 9, pp. 1809-1817.

Lockett, A., Siegel, D., Wright, M., and Ensley, M. D. (2005) 'The creation of spin-off firms at public research institutions: Managerial and policy implications', Research Policy, 34(7), pp. 981-993.

Lockett, A., and Wright, M. (2005) 'Resources, capabilities, risk capital and the creation of university spin-out companies', Research Policy, 34(7), pp. 1043-1057.

Mathisen, M. T., and Rasmussen, E. (2019) The development, growth, and performance of university spin-offs: a critical review, Journal of Technology Transfer. Springer US.

McAdam, M., Miller, K., and McAdam, R. (2016) 'Situated regional university incubation: A multi-level stakeholder perspective', Technovation. Elsevier, 50-51, pp. 69-78.

McAdam, M., Miller, K., and McAdam, R. (2018) 'Understanding Quadruple Helix relationships of university technology commercialisation: a micro-level approach', Studies in Higher Education. Taylor \& Francis, 43(6), pp. 1058-1073.

Mollick, E. (2014) 'The dynamics of crowdfunding: An exploratory study', Journal of Business Venturing. The Author, 29(1), pp. 1-16.

Muparadzi, A., and Caesar, L. D. (2020) 'Examining the dynamics of industry-university collaborations in Ghana', Journal of Applied Research in Higher Education. 
INTERNATIONAL JOURNAL OF ACADEMIC RESEARCH IN ACCOUNTING, FINANCE AND

\section{MANAGEMENT SCIENCES}

Vol. 11, No. 1, 2021, E-ISSN: 2225-8329 @ 2021 HRMARS

Muscio, A., Quaglione, D., and Ramaciotti, L. (2016) 'The effects of university rules on spinoff creation: The case of academia in Italy', Research Policy. Elsevier B.V., 45(7), pp. 1386-1396.

Okebukola, P. A. (2015) 'Towards Innovative Models for Funding Higher Rducation in Africa', Association of African Universities, pp. pp3-10.

Prainsack, B. (2012) 'Elias G. Carayannis and David F. J. Campbell, Mode 3 Knowledge Production in Quadruple Helix Innovation Systems: 21st-Century Democracy, Innovation, and Entrepreneurship for Development', Minerva, 50(1), pp. 139-142.

Ramaciotti, L., and Rizzo, U. (2015) 'The determinants of academic spin-off creation by Italian universities', $R$ and D Management, 45(5), pp. 501-514.

Smith, H. L., and Romeo, S. (2012) 'Entrepreneurship and innovation: Oxfordshire's high- tech economy - firm survival, growth and innovation', Entrepreneurship, Social Capital and Governance: Directions for the Sustainable Development and Competitiveness of Regions, (May), pp. 27-52.

Soetanto, D., and Van Geenhuizen, M. (2015) 'Getting the right balance: University networks' influence on spin-offs' attraction of funding for innovation', Technovation. Elsevier, 36, pp. 2638.

Thorne, S. (2000) 'EBN notebook Data analysis in qualitative research', EBN Notebook, 3, pp. 68-70.

Wright, M., Lockett, A., Clarysse, B. and Binks, M. (2006) 'University spin-out companies and venture capital', Research Policy, 35(4), pp. 481-501. 